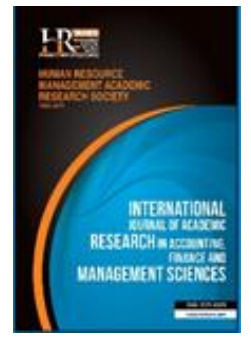

International Journal of Academic Research in Accounting, Finance and Management Sciences

Vol. 8, No.2, April 2018, pp. 178-199

E-ISSN: 2225-8329, P-ISSN: 2308-0337

(C) 2018 HRMARS

www.hrmars.com

To cite this article: Okeke, M.N., Mbonu, C.M., Ndubuisi, A.N. (2018). Tax Revenue and Economic Development in Nigeria: A Disaggregated Analysis, International Journal of Academic Research in Accounting, Finance and Management Sciences 8 (2): 178-199.

\title{
Tax Revenue and Economic Development in Nigeria: A Disaggregated
} Analysis

\author{
Moses Nnoruga OKEKE ${ }^{1}$, Chikwelu M. MBONU², Amahalu Nestor NDUBUISI ${ }^{3}$ \\ ${ }_{1,2}$ Department of Accountancy, Federal Polytechnic, OKO, Anambra State, \\ ${ }^{1}$ E-mail: mosesnnoruga@yahoo.com, 22E-mail: chikwelumbonu@gmail.com \\ ${ }^{3}$ Department of Accountancy, Nnamdi Azikiwe University, Awka, Anambra State, ${ }^{3}$ E-mail: nn.amahalu@unizik.edu.ng

\begin{abstract}
The objective of this study is to ascertain the relationship between tax revenue and economic development in Nigeria during the period 1994 -2016. Data were obtained from the Central Bank of Nigeria, Office of the Federal Inland Revenue Service and Annual Abstract of statistics of the National Bureau of Statistics. This study was based on time series data. The Augmented Dickey Fuller test, Multple linear regression, Multicollinearity test, Granger Causality test, Johansen cointegration test and Error correction model were employed in the analysis of the data. The findings of this study showed that tax revenue has a statistically significant relationship with infant mortality, labour force and gross fixed capital formation in Nigeria at 5\% level of significance respectively. On the basis of the findings, it was recommended among others that since tax revenue has been proven to contribute to economic development in Nigeria, Government needs to increase its allocation to the priority sectors of the economy such as agriculture and industry in order improve on the
\end{abstract} \\ welfare of the citizenry.
}

Key words Tax revenue, infant mortality, labour force, Gross Fixed Capital Formation

\begin{tabular}{|c|c|c|}
\hline Received: & 01 Jun 2018 & (C) The Authors 2018 \\
\hline Revised: & 18 Jun 2018 & Published by Human Resource Management Academic Research Society (www.hrmars.com) \\
\hline & 28 Jun 2018 & $\begin{array}{l}\text { This article is published under the Creative Commons Attribution (CC BY } 4.0 \text { ) license. Anyone may } \\
\text { reproduce distribute translate and create derivative works of this article (for both commercial and non- }\end{array}$ \\
\hline ed Online: & 12 Jul 2018 & $\begin{array}{l}\text { commercial purposes), subject to full attribution to the original publication and authors. The full terms of } \\
\text { this license may be seen at: http://creativecommons.org/licences/by/4.0/legalcode }\end{array}$ \\
\hline
\end{tabular}

\section{Introduction}

Taxation is a major source of government revenue all over the world and governments use tax proceeds to render their traditional functions, such as: the provision of goods, maintenance of law and order, defence against external aggression, regulation of trade and business to ensure social and economic maintenance (Edame and Okoi, 2014). A system of tax avails itself as a veritable tool that mobilizes a nation's internal resources and it lends itself to creating an environment that is conducive for the promotion of economic growth (Ayuba, 2014). Therefore, taxation plays a major role in assisting a country to meet its needs and promote self-reliance. The need for tax payments has been a phenomenon of global significance as it affects every economy irrespective of national differences (Oboh and Isa, 2012).

In more recent times, renewed attention was paid to the role of human capital formation in the country's development process and this has prompted the federal government to declare in its 1999-2003 economic policy programme that the economy exists for and belongs to the people, and at all times the general objectives of the government and the proper measure of performance (Federal Government of Nigeria, 1999). This policy statement of the government is further reiterated in the National Economic Empowerment and Development Strategy (NEEDS). The provision of high quality education and health care 
to all the country's citizen is considered a key element of public policy by all levels of government (Abiahu and Amahalu, 2017).

Little wonder Galbraith (1960) remarks on America's economy that, "we now get the larger part of our industrial growth not from more capital investment but from investment in men and improvements brought about by improved men" (Galbraith, 1960). No country has achieved sustained economic development without substantial investment in human capital. The role and importance of human capital in propelling the pace of economic growth cannot be overemphasized. The development of human capital has been recognized by economists and accountants to be a key prerequisite for a country's socioeconomic and political transformation. Therefore, human capital is considered as the most valuable asset and needs to be mobilized, developed and empowered to participate fully in all socio-economic activities.

Taxation is an age long event (Amahalu and Ezechukwu, 2017). Tax is a compulsory charge imposed by a public authority on the income and properties of individuals and companies as stipulated by the government Decree, Acts or Laws irrespective of the exact amount of service of the payer in return (Omotoso, 2001). Tax payment is not for the direct exchange of good and/or services but a transfer of resources and income from the private sector to the public sector in order to achieve some of the nation's economic and social goals (Okpe, 2000). Such goals may be in for a high level of employment, stable prices, rapid growth of gross national product, favourable balance of payments position, promotion of a free market economy, satisfaction of collective demands, equitable income redistribution, promotion of infant industries, the encouragement of priority sector, promotion of labour and capital development (Onoh, 2013). The level of tax to be paid by the citizens and the items to be taxed is determined by the government. Such decision according to Ngerebo and Masa (2012) is based on the cost of the projects or programmes government intends to execute, which is the principal determinant of the budget size. Government also judges the basis, rates, the category of citizens, and the time period to pay the tax, on the direction of the economy desired and government's perception of the standard of living of the citizens. Taxes therefore affect the expenditure size of government, the productivity and level of activities of businesses, the consumption pattern of individuals, the propensity to save and invest and the growth path of the economy (Amahalu et al., 2017).

In Nigeria the incidence of tax evasion and avoidance by tax payers is high, leading to low level of government revenue which further reduces the level of government expenditure, culminating into a reduction in the income savings and expenditure of households and firms, leading to low level of economic activities and economic growth (Fagbemi et al., 2010). Government needs money to be able to execute its social obligations to the public and these social obligations include but not limited to the provision of infrastructure and social services. According to Murkur (2001), meeting the needs of the society calls for huge funds which an individual or society cannot contribute alone and one medium through which fund is derived is through taxation. Tax is a major source of government revenue all over the world. Government use tax proceeds to render their traditional functions, such as the provision of public goods, maintenance of law and order, defence against external aggression, regulation of trade and business to ensure social and economic maintenance (Azubike, 2009; Edame, 2008).

\subsection{Statement of the Problem}

Nigeria is said to be deficient in human capital and infrastructure and as a developing economy, one of the defining features of its growth would be underpinned by the improvement of human capital and massive development of physical infrastructure. Human capital development has been found to play a crucial role in appropriating the gains of foreign direct investment (FDI) with host country and all levels of development especially, in creating the ability to absorb, assimilate and diffuse imported technology. As information grows exponentially, and as its incorporation in the production process becomes increasingly complex, the ability to acquire, adopt and adapt new knowledge becomes an important determinant of economic growth (Isola and Alani 2002).

Development of infrastructure (good road network, modern communication, adequate electricity supply, good institutions, water supply, sanitation and sewerage and so on) has been widely cited as a crucial factor in economic growth (Amahalu et al., 2017). Good infrastructure facilitates production, reduces operation costs and increases the productivity of investment and thereby enhances economic 
development. It also provides employment opportunities to the poor. Regrettably, what is prominent in the debate of less developed countries (LDCS) is hinged on poor human capital and deficient infrastructure and institutions (Collier and Gunning, 1999, Soludo, 1998), poor economic policies and quality of governance (World Bank, 1994), and the quality of human development/capacity. Infrastructure are public goods and services that goes into the production process as complementary inputs for traditional factors of production such as capital, labour and Entrepreneur. They help to increase returns on investment by reducing production cost and improving transition efficiency. The availability of infrastructure facilities and services as well as the efficiency of such services to a large extent determine the success or otherwise of all other production endeavours. Investments in infrastructures such as energy, water, transportation and communication technologies promote economic growth and help to alleviate poverty and improve living conditions in developing countries.

The high cost of education and inadequate investment in infrastructure has made Nigeria to be ranked 158 in the human development and infrastructure index, with value of 0.451 among 187 countries which places her in the bottom of the table. This implies that Nigeria is below the Sub-regions level of human development index which is very worrisome. The decay of Nigeria's educational system, coupled with the high cost of schooling and low returns, and the absence of competition in most essential infrastructural institutions, like roads, electricity, sea ports and air ports have put Nigeria on this low scale.

\subsection{Objectives of the Study}

The broad objective of this study is to ascertain the effect of tax revenue on economic development in Nigeria. The specific objectives are to;

1. Evaluate the effect of tax revenue on infant mortality (IM) in Nigeria;

2. Identify the effect of tax revenue on labour force (LF) in Nigeria;

3. Ascertain the effect of tax revenue on gross fixed capital formation (GFCF) in Nigeria.

\subsection{Research Hypotheses}

The following hypotheses are formulated for this study and are stated in null form:

$\mathrm{Ho}_{1}$ : Tax Revenue has no significant effect on infant immortality in Nigeria

$\mathrm{Ho}_{2}:$ Tax Revenue has no significant effect on labour force in Nigeria

$\mathrm{Ho}_{3}$ : Tax Revenue has no significant effect on gross fixed capital formation in Nigeria

\section{Literature review}

\subsection{Taxation and Economic Development}

The major challenge of national governments worldwide is to perpetually increase the welfare of the citizenry through the implementation of appropriate economic policies and programs by direct participation in domestic and global economic activities. Governments attempt to achieve this national objective by providing public goods, such: as roads, bridges, dams, ports and public services such as education, security, health, sanitation etc that form economic and social infrastructure. The adequacy of such infrastructure is a turn foundation for a country's economic growth and development. Ideally, all public expenditures should: contribute to the creation and fostering of an enabling domestic economic environment for local and foreign investments; boost both internal and external trade; attract tourists and other foreign visitors; increase agricultural productivity; and encourage craftsmanship and small scale industrial production. All these economic activities generate gainful employment and accelerate economic growth and development in the short, medium and long terms.

The relationship between taxation and economic development has been studied with different findings (for instance, Oremade, 2006; Okoli, 2014; Devaranjan, 1996)

\subsection{Taxation}

Going by the definition of taxation, Nzotta (2007) identified four key issues which must be understood for taxation to play its functions in any society. First, a tax is a compulsory contribution made by the citizens to the government and this contribution is for general common use. Secondly, a tax imposes 
a general obligation on the tax payer. Thirdly, there is a presumption that the contribution to the public revenue made by the tax payer may not be equivalent to the benefits received. Finally, a tax is not imposed on a citizen by the government because it has rendered specific services to him or his family. Thus, it is evident that a good tax structure plays a multiple role in the process of economic development of any nation which Nigeria is not an exception (Appah, 2010).

\subsection{Personal Income Tax}

Personal income tax is a levy imposed by the government of a country on its citizens, individual or entities known as the taxpayers. The levy imposed on the taxpayers is such that it varies with the level of income or profits of the taxpayers. Taxes imposed on the personal income of an individual taxpayer are termed "Personal Income Tax". Thus, personal income tax signifies taxes imposed on the personal income of the individual. These taxes are imposed on the income of the individual on a basis of "Pay as You Earn" (PAYE) and the individual taxpayer must be an employed person and expected to file returns on a yearly basis.

\subsection{Company Income Tax}

Company Tax is established by the Companies Income Tax Act (CITA) CAP C21 2004 LFN for both resident and non-resident companies in Nigeria. All companies in Nigeria are liable to pay companies Income Tax on their global profits accruing in, brought into, derived from or received in Nigeria. However, the Companies Income Tax Act (CITA) defines company in a broader sense. It defines a company as any company or corporation (other than corporation sole) established by or under any law in force in Nigeria or elsewhere. The tax rate applied to small companies is $20 \%$ on the taxable profit instead of the $30 \%$ of a normal trade or business.

\subsection{Value Added Tax}

VAT is established by the Value Added Tax Act Cap VI, 2004 LFN. This Act replaced the Sales Tax in operation under the Federal Government legislated decree No. 7 of 1986. The Value Added Tax is a special type of indirect tax in which a sum of money is levied at each stage of production and distribution of a product or service. VAT refers to the tax on the value added. The value added of a firm is the difference between a firm's sales and its purchases of inputs from other firms. In other words, it is the amount of value a firm contributes to a good or service by applying its own factors of production namely land, labor, capital and entrepreneurial ability. In Nigeria VAT is charged at a flat rate of $5 \%$ on selected items of goods and services. Though, exemption is granted in respect of medical and pharmaceutical products, basic food items.

\subsection{Petroleum Profit Tax in Nigeria}

Petroleum profit tax Act is a legislation which imposes tax upon profits from the mining of petroleum in Nigeria and provides for the assessment and collection thereof and for the purposes connected therewith. The applicable law is the Petroleum Profits Tax Act (PPTA), which was first enacted in 1959 with retrospective effective date of 1 January, 1958. This principal Act and all amendments thereto have been re-enacted as Chapter P13 of the Laws of the Federation of Nigeria (LFN) 2004. Petroleum profit tax (PPT) is a tax applicable to upstream operations in the oil industry. It is particularly related to rents, royalties, margins and profit sharing elements associated with oil mining, prospecting and exploration leases. It is the most important tax in Nigeria in terms of its share of total revenue contributing 95 and 70 percent of foreign exchange earnings and government revenue, respectively.

\subsection{Export Duty}

The export duty represents a tax which is applied to the exported goods, by the customs authorities of a country. This is a part of the international trade policy of a country, used to raise state revenue. The export tax or customs tariff is based on the value of products or their weight or dimensions. Export duties consist of general or specific taxes on goods or services that become payable when the goods leave the 
economic territory or when the services are delivered to non-residents; profits of export monopolies and taxes resulting from multiple exchange rates are excluded (OECD, 2001).

\subsection{Import Duty}

Import duty is a tax collected on imports by the customs authorities of a country. It is usually based on the value of the goods that are imported. Depending on the context, import duty may also be referred to as customs duty, tariff, import tax and import tariff. There are two distinct goals to import duties: to raise income for local government, and to give a market advantage to locally grown or produced goods that are not subject to import duties. A third related goal is sometimes to penalize a particular nation by charging high import duties on its products. Ultimately for consumers, the cost of the duty is added to the price paid for the good. As such, all other things being equal, the exact same good produced internally should cost less, giving an advantage to the local producers.

\subsection{Infant Mortality}

Infant mortality rate is defined as the death of an infant before his or her first birthday. It is a useful indicator on the nation's health because it is often associated with other health factors such as maternal health, quality and accessibility of medical care, and socioeconomic conditions.

\subsection{Labour Force}

The labour force participation rate is a measure of the proportion of a country's working-age population that engages actively in the labour market, either by working or looking for work; it provides an indication of the size of the supply of labour available to engage in the production of goods and services, relative to the population at working age.

\subsection{Gross Fixed Capital Formation}

Capital Formation is an important indicator to measure the economic development and indicate the magnitude of growth of productive potential of an economy. Higher the growth rate of Capital Formation, higher would be productivity capacity of the economy, whereas its paucity leads to low level of production with higher cost. The Central Bank of Nigeria (2007), defines capital formation as the total change in the value of fixed assets in the economy in addition to fixed assets either for replacing or adding to the stocks, it refers to the increase in the fixed capital stocks of the capital formed.

\subsection{Economic Development}

Economic development requires collective action and large-scale, long-horizon investment. Economic development addresses the fundamental conditions necessary for the micro economic functioning of the economy. It is within the purview of government. Though it is certainly possible to have growth without development in the short or even medium-term, economic development creates the conditions that enable long-run economic growth. Jobs are a main concern of policy: for growth what matters is the number of jobs while for economic development the focus is wages, career advancement opportunities, and working conditions (Feldman and Francis, 2003).

\subsection{Taxation and Infant Mortality}

Child mortality is a fundamental measurement of a country's level of socio-economic development as well as the quality of life especially of the mothers. Under-five mortality rate represents the probability of a child who survives to age one, dying between age one and age five (World Health Organisation, 2011). Almost half of the child mortality (42\%) in the world occurs in Africa and about 25,000 under-five children that die each day are concentrated in sub-Saharan Africa and South Asia (WHO, 2011). Under-five mortality rate (U5MR) is generally 29 times higher in developing nations compared to developed countries (Black \& Liu, 2012; Gambrah and Adzadu, 2013). Globally, under-five mortality has dropped significantly by almost 45 percent between 2009 and 2011 but this progress is not the reality for all countries. Despite much progress in advanced countries, Nigeria has failed to make significant progress in checking the rising 
mortality rate among the under-five. Currently, about half of the world's under-five deaths occur in Nigeria, India, Congo, Pakistan and China (National Bureau of Statistics, 2011; World Bank, 2013).

\subsection{Taxation and Labour Force}

Ihendinihu et al. (2014) used Autoregressive Distributed Lag (ARDL)/Bounds Test General to Specific Approach to Cointegration to assess the long run equilibrium relationship between tax revenue and economic growth in Nigeria (1986-2012) and found that total tax revenue has significant effect on economic growth. With about $73.4 \%$ of the total variations in the real gross domestic product (economic growth) explained by aggregate changes in all the tax revenue components in the model, the study however, identified no significant causal link between.

\subsection{Taxation and Gross Fixed Capital Formation}

The rate of growth in Nigeria economy cannot be fully analyzed without a closer look at the contribution of capital formation to Nigeria's economic development. This is in the understanding that capital formation has been recognized as an important factor that determines the growth of Nigerian economy. According to Bakare (2011), capital formation refers to the proportion of present income saved and invested in order to augment future output and income. It usually results from acquisition of new factory along with machinery, equipment and all productive capital goods.

\section{Methodologyof research}

\subsection{Theoretical Review}

This study is anchored on Exogenous growth model:

Exogenous growth model

The exogenous growth model, also known as the neo - classical growth model or Solow-Swan growth model was first devised by Nobel Prize winning Economist, Robert Solow in 1957. The model believes that a sustained increase in capital investment increases the growth rate only temporarily; because the ratio of capital to labour goes up but the marginal product of additional units of capital is assumed to decline and the economy eventually moves back to a long - term growth path, with real GDP growing at the same rate as the work force plus a factor to reflect improving productivity. A steady - state growth path is reached when output, capital and labour are all growing at the same rate, so that output per worker and capital per worker are constant. The centrepiece of the standard neoclassical growth model developed by Solow (1957) is an aggregate production function of the form:

$$
Y t=F(K t, L t, A t)
$$

Where $\mathrm{Y}$ is output, $\mathrm{K}$ is capital, $\mathrm{L}$ is labour and $\mathrm{A}$ is an index of technology or efficiency.

\subsection{Empirical Review}

Odo et al. (2016) examined the effect of human capital development on the growth of Nigeria economy. Using co integration techniques to investigate the effect of human capital development and economic growth in Nigeria, the result obtained was that there is significant long-run relationship between human capital development and economic growth in Nigeria.

Mba et al. (2013) evaluated the relevance of human capital development on the growth of the economy pin pointing the relationship that exists between them. In this study, the ordinary least square (OLS) technique was adopted. The GDP was used as a proxy for economic growth; Per Capital Real Gross Domestic Product, primary school enrolment, public expenditure on education and health, life expectancy, stock of physical capital as proxy for human capital. From the analysis, it was deduced that there is a strong positive relationship between human capital development and economic growth.

Abu and Abdullahi (2010) investigated the effect of government expenditure on economic growth; the study employed a disaggregated analysis. The results revealed that government total capital expenditure (TCAP), total recurrent expenditures (TREC), and government expenditure on education (EDU) 
have negative effect on economic growth. On the contrary, rising government expenditure on transport and communication (TRACO), and health (HEA) resulted to an increase in economic growth.

\subsection{Research Design}

The research design employed in this study is the Longitudinal Research Design, since the data is time series data.

\subsection{Sources of Data}

The nature of data for this study was essentially secondary data and is time series in nature. The scope of this study spanned from 1994-2016, a 23-year period. The data were sourced from the of Central Bank of Nigeria (CBN), Statistical Bulletin Office of the Federal Inland Revenue Services (FIRS), Federal Inland Revenue Service (FIRS), World Bank Statistical Bulletin and Annual Abstract of Statistics from the National Bureau of Statistics (NBS).

\section{Research Variables}

\section{Independent Variables}

The independent variable in this study is taxation which will be decomposed into: (i) Petroleum Profit tax (PPT): Obtained from Federal Inland Revenue Service (FIRS) statistical bulletin (various issues); (ii) Company Income Tax (CIT): Obtained from Federal Inland Revenue Service (FIRS) statistical bulletin (various issues); (iii) Value Added Tax (VAT): Obtained from Federal Inland Revenue Service (FIRS) statistical bulletin (various issues); (iv) Personal Income Tax (PIT): Obtained from Federal Inland Revenue Service (FIRS) statistical bulletin (various issues); (v) Export Duty (EXDT): Obtained from Federal Inland Revenue Service (FIRS) statistical bulletin (various issues); (vi) Import Duty: Obtained from Federal Inland Revenue Service (FIRS) statistical bulletin (various issues).

\section{Dependent Variables}

The dependent variable is economic development, which is proxied by:

i. Infant Mortality (IM): Collected from Central Bank of Nigeria Statistical Bulletin, World Bank Statistical Bulletin and National Bureau of Statistics (various issues).

ii. Labour Force (LF): Collected from Central Bank of Nigeria Statistical Bulletin, World Bank Statistical Bulletin and National Bureau of Statistics (various issues).

iii. Gross Fixed Capital Formation (GFCF): Collected from Central Bank of Nigeria Statistical Bulletin, World Bank Statistical Bulletin and National Bureau of Statistics (various issues).

\subsection{Model Specification}

This study specifies a functional relationship between economic development and taxation.

Generally the model is specified as:

$Y=\beta_{0}+\beta X_{1}+\mu$

Where:

$Y$ =Economic development (Dependent Variable);

$\mathrm{X}=$ Taxation (Explanatory/Independent Variable);

$\beta_{0}=$ Constant term (Intercept);

$\beta=$ Coefficient of taxation;

$\mu=$ Error term (Stochastic Term).

Explicitly, the equation can be defined as:

Economic development $=f($ taxation $)+\mu$

Representing the equations with the variables of the construct, hence the equations below are formulated: 


$$
\begin{aligned}
& \mathrm{IM}=\beta_{0}+\beta_{1} \mathrm{PIT}+\beta_{2} \mathrm{CIT}+\beta_{3} \mathrm{VAT}+\beta_{4} \mathrm{PPT}+\beta_{5} \mathrm{EXDT}+\beta_{6} \mathrm{IMDT}+\mu \\
& \mathrm{LF}=\beta_{0}+\beta_{1} \mathrm{PIT}+\beta_{2} \mathrm{CIT}+\beta_{3} \mathrm{VAT}+\beta_{4} \mathrm{PPT}+\beta_{5} \mathrm{EXDT}+\beta_{6} \mathrm{IMDT}+\mu \\
& \mathrm{GFCF}=\beta_{0}+\beta_{1} \mathrm{PIT}+\beta_{2} \mathrm{CIT}+\beta_{3} \mathrm{VAT}+\beta_{4} \mathrm{PPT}+\beta_{5} \mathrm{EXDT}+\beta_{6} \mathrm{IMDT}+\mu
\end{aligned}
$$

\section{A Priori expectation}

The theoretical (a priori) expectations about the signs of the coefficients are as follows: $\beta 0>0, \beta_{1}>0$, $\beta_{2}>0, \beta_{3}>0, \beta_{4}>0, \beta_{5}>0, \beta_{6}>0$

It is expected that the sign of the coefficients of PIT, CIT, VAT, PPT, EXDT and IMDT should be positive. This is because an increase in the amount of PIT, CIT, VAT, PPT, EXDT and IMDT will lead to an increase in IM, LF and GFCF other factors being equal.

Decision Rule

Accept the alternative hypothesis, if the P-value of the test is less than 0.05 . Otherwise reject.

\subsection{Data Presentation}

\section{Test of Reliability}

The researcher tested for stationarity unit root test in order to fulfill the economic theory which states that variables that must enter a regression model must undergo a stationarity test in order to achieve a realistic (non spurious) result at $1 \%, 5 \%$ or $10 \%$ level of significance. The result for the test is shown below in table 1 . The data used in this study had unit root problem, consequently, the data were detrended using Augmented Dickey-Fuller Test. The result of the differenced data in order to solve the unit root problem is shown in table 1 .

Table 1. Differenced Result

\begin{tabular}{ccccccc}
\hline \multirow{2}{*}{ Variables } & Test Statistic & \multicolumn{3}{c}{ Test Critical Values } & Status & \multirow{2}{*}{ Prob. } \\
& ADF & 1\% level & 5\% level & 10\% level & Stationary & \\
\hline CIT & -11.42380 & -3.808546 & -3.020686 & -2.650413 & $1(1)$ & 0.0000 \\
EXDT & -8.897032 & -3.857386 & -3.040391 & -2.660551 & $1(1)$ & 0.0000 \\
GFCF & -4.921203 & -3.808546 & -3.020686 & -2.650413 & $1(1)$ & 0.0009 \\
IM & -4.083546 & -3.788030 & -3.012363 & -2.646119 & $1(1)$ & 0.0053 \\
IMDT & -7.299352 & -3.788030 & -3.012363 & -2.646119 & $1(1)$ & 0.0000 \\
LF & -4.429780 & -3.788030 & -3.012363 & -2.646119 & $1(1)$ & 0.0025 \\
PIT & -5.022744 & -3.788030 & -3.012363 & -2.646119 & $1(1)$ & 0.0007 \\
PPT & -4.608579 & -3.788030 & -3.012363 & -2.646119 & $1(1)$ & 0.0017 \\
VAT & -4.014750 & -3.788030 & -3.012363 & -2.646119 & $1(1)$ & 0.0287 \\
\hline
\end{tabular}

Source: Researcher's computation using E-view 9.0, 2018

Table 2. Test for Multicollinearity

Variance Inflation Factors

Date: 03/05/18 Time: 10:17

Sample: 19942016

Included observations: 22

\begin{tabular}{lccc} 
Variable & $\begin{array}{c}\text { Coefficient } \\
\text { Variance }\end{array}$ & $\begin{array}{c}\text { Uncentered } \\
\text { VIF }\end{array}$ & $\begin{array}{c}\text { Centered } \\
\text { VIF }\end{array}$ \\
\hline \hline C & $9.19 \mathrm{E}-05$ & 2.167063 & NA \\
DPIT & 0.004834 & 2.842265 & 2.326432 \\
DCIT & 0.004144 & 1.527954 & 1.429024 \\
DVAT & 0.040166 & 4.356373 & 2.157837 \\
DPPT & 0.001819 & 1.453145 & 1.399233 \\
DEXDT & 0.001430 & 2.116305 & 1.867467 \\
DIMDT & 0.001842 & 1.819340 & 1.467553 \\
\hline \hline
\end{tabular}

Source: Researcher's computation using E-View 9.0, 2018 
Interpretation

Table 2 shows that the variance inflation factor (VIF) is less than 10. This is an indication of non existence of multicollinearity among the variables in the model (Kothari and Garg, 2014).

Test of Hypothesis I

$\mathrm{Ho}_{1}$ : Tax Revenue has no significant effect on IM in Nigeria

$\mathbf{H}_{\mathbf{1}}$ : Tax Revenue has significant effect on IM in Nigeria

Model Specification

$I M=\beta_{0}+\beta_{1} P I T+\beta_{2} C I T+\beta_{3} V A T+\beta_{4} P P T+\beta_{5} E X D T+\beta_{6} I M D T+\mu-H o_{1}$

Table 3. Multiple Regression Analysis showing the relationship between DPIT, DCIT, DVAT, DPPT, DEXDT, DIMDT and DIM

Dependent Variable: DIM

Method: Least Squares

Date: 03/06/18 Time: 08:22

Sample (adjusted): 19952016

Included observations: 22 after adjustments

\begin{tabular}{lclcc}
\hline \hline \multicolumn{1}{c}{ Variable } & Coefficient & Std. Error & t-Statistic & Prob. \\
\hline \hline C & 0.006234 & 0.013097 & 3.475964 & 0.0010 \\
DPIT & -0.082115 & 0.094987 & -8.864486 & 0.0000 \\
DCIT & -0.037801 & 0.087950 & -4.429801 & 0.0005 \\
DVAT & 0.151517 & 0.273798 & 6.553391 & 0.0000 \\
DPPT & 0.040619 & 0.058266 & 2.697124 & 0.0264 \\
DEXDT & -0.044284 & 0.051661 & -3.857198 & 0.0048 \\
DIMDT & -0.029166 & 0.058633 & -3.497432 & 0.0061 \\
\hline \hline R-squared & 0.815326 & Mean dependent var & 0.001818 \\
Adjusted R-squared & 0.738544 & S.D. dependent var & 0.037497 \\
S.E. of regression & 0.041731 & Akaike info criterion & -3.261779 \\
Sum squared resid & 0.026122 & Schwarz criterion & -2.914629 \\
Log likelihood & 42.87956 & Hannan-Quinn criter. & -3.180000 \\
F-statistic & 19.32589 & Durbin-Watson stat & 1.716859 \\
Prob(F-statistic) & 0.000000 & & \\
\hline \hline
\end{tabular}

Source: Researcher's computation using E-View 9.0, 2018

\section{Interpretation of Regression Result}

According to the result of the analyzed data in table 3 , the function of multiple regressions was built in the model below:

$\mathrm{DIM}=0.006234-0.082115 \mathrm{DPIT}-0.037801 \mathrm{DCIT}+0.151517 \mathrm{DVAT}+0.040619 \mathrm{DPPT}-0.044284 \mathrm{DEXDT}-$ $0.029166 \mathrm{DIMDT}$.

The results of the multiple regressions exploring the functional relationship between DPIT, DCIT, DVAT, DPPT, DEXDT, DIMDT and DIM are presented in table 4.18. The results showed that DVAT and DPPT have a direct/positive relationship with DIM while DPIT, DCIT, DEXDT and DIMDT have negative relationship with DIM in Nigeria. That is, infant mortality is significantly influenced by the explanatory variables. The result also showed that the explanatory variables are statistically significant in explaining variations in infant mortality at $5 \%$ level of significance. Testing the overall significance of the model, the results also confirmed that the model is statistically significant at $5 \%$ level of significance with the Prob(Fstatistic) $=0.000000$. Durbin-Watson statistics of 1.716859 showed that the data are free from problem of serial correlation. 
Decision Rule

Accept the alternative hypothesis $\left(\mathrm{H}_{1}\right)$ if the $\mathrm{p}$-value of the test is less than 0.05 , otherwise reject.

Decision:

The P-value of the test is 0.000000 which is less than the critical P-value of 0.05 . Hence, $\mathrm{H}_{\mathrm{o}}$ is rejected and $\mathrm{H}_{1}$ is accepted.

Conclusion

Since there is strong evidence that infant mortality is influenced by tax revenues at $5 \%$ level of significance. This study concludes that taxation has significant influence on infant mortality in Nigeria for the period of 1994 to 2016.

Table 4. Granger Causality Test showing the Causality between DPIT, DCIT, DVAT, DPPT, DEXDT, DIMDT and DIM

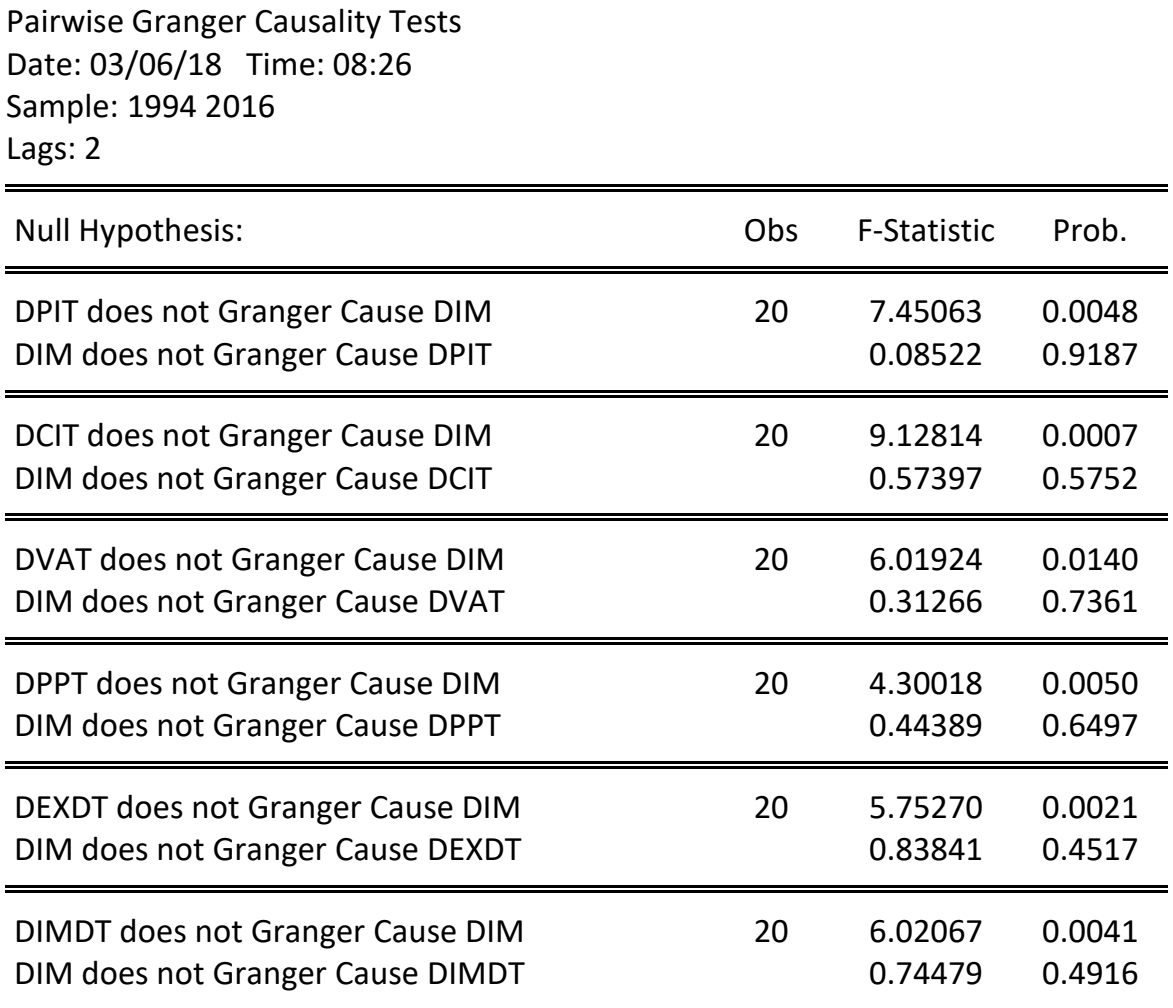

Source: Researcher's computation using E-View 9.0, 2018

Interpretation of Post Regression Analysis

Table 4 shows that there is a unilateral causality between DPIT, DCIT, DVAT, DPPT, DEXDT, DIMDT and DIM, since the P-values are statistically significant at $5 \%$ level. Moreover, at two (2) lags there is a statistically significant relationship between DPIT, DCIT, DVAT, DPPT, DEXDT, DIMDT and DIM. On the other hand, there is no reverse causation from DIM to DPIT, DCIT, DVAT, DPPT, DEXDT, DIMDT. This establishes the fact that DPIT, DCIT, DVAT, DPPT, DEXDT, DIMDT Granger Causes DIM. Consequently, the null hypothesis is rejected for the alternative which states that DPIT, DCIT, DVAT, DPPT, DEXDT, DIMDT has a statistically significant effect on DIM in Nigeria at $5 \%$ level of significance.

Table 5. Johansen Co-integration Test

Date: 03/06/18 Time: 08:34

Sample (adjusted): 19962016

Included observations: 21 after adjustments

Trend assumption: Linear deterministic trend

Series: DIM DPIT DCIT DVAT DPPT DEXDT DIMDT

Lags interval (in first differences): No lags 
Unrestricted Cointegration Rank Test (Trace)

\begin{tabular}{lcccc}
\hline $\begin{array}{c}\text { Hypothesized } \\
\text { No. of CE(s) }\end{array}$ & Eigenvalue & $\begin{array}{c}\text { Trace } \\
\text { Statistic }\end{array}$ & $\begin{array}{c}0.05 \\
\text { Critical Value }\end{array}$ & Prob.** \\
\hline \hline None & 0.934236 & 166.6330 & 125.6154 & 0.0000 \\
At most 1 & 0.901099 & 159.4777 & 105.7536 & 0.0000 \\
At most 2 & 0.876323 & 136.5932 & 98.81889 & 0.0003 \\
At most 3 & 0.816893 & 126.9437 & 87.85613 & 0.0008 \\
At most 4 & 0.777109 & 106.7954 & 79.79707 & 0.0017 \\
At most 5 & 0.610682 & 93.17946 & 65.49471 & 0.0084 \\
At most 6 & 0.594080 & 72.07488 & 53.84466 & 0.0097 \\
\hline \hline
\end{tabular}

Trace test indicates 7 cointegrating eqn(s) at the 0.05 level

$*$ denotes rejection of the hypothesis at the 0.05 level

**MacKinnon-Haug-Michelis (1999) p-values

Unrestricted Cointegration Rank Test (Maximum Eigenvalue)

\begin{tabular}{lcccc}
\hline \hline $\begin{array}{l}\text { Hypothesized } \\
\text { No. of CE(s) }\end{array}$ & Eigenvalue & $\begin{array}{c}\text { Max-Eigen } \\
\text { Statistic }\end{array}$ & $\begin{array}{c}0.05 \\
\text { Critical Value }\end{array}$ & Prob. ${ }^{*}$ \\
\hline None & 0.934236 & 107.15531 & 96.23142 & 0.0000 \\
At most 1 & 0.901099 & 102.88376 & 90.07757 & 0.0000 \\
At most 2 & 0.876323 & 99.65018 & 83.87687 & 0.0000 \\
At most 3 & 0.816893 & 93.14827 & 77.58434 & 0.0003 \\
At most 4 & 0.777109 & 83.61601 & 71.13162 & 0.0019 \\
At most 5 & 0.610682 & 77.10458 & 64.26460 & 0.0062 \\
At most 6 & 0.594080 & 72.07488 & 53.84466 & 0.0097 \\
\hline \hline
\end{tabular}

Max-eigenvalue test indicates 7 cointegrating eqn(s) at the 0.05 level

* denotes rejection of the hypothesis at the 0.05 level

**MacKinnon-Haug-Michelis (1999) p-values

Source: Researcher's computation using E-View 9.0, 2018

\section{Interpretation of Diagnostic Result}

In table 5, the Johansen co-integration test was used to determine the existence of long-run equilibrium relationship among the variables under study. The Trace Statistic value and Max-Eigen Statistic are shown to be greater than the critical values at $1 \%$ and $5 \%$ levels, thus indicating 7 co-integrating equation at $5 \%$ levels. Therefore, the null hypothesis is rejected and it is concluded that there exists long run equilibrium relationship between the dependent variable (DIM) and independent variables (DPIT, DCIT, DVAT, DPPT, DEXDT, DIMDT). This implies that the regression model is not spurious and the conclusion thereof is valid.

Table 6. Error Correction Model

Vector Error Correction Estimates

Date: 03/06/18 Time: 09:41

Sample (adjusted): 19962016

Included observations: 21 after adjustments

Standard errors in ( ) \& t-statistics in [ ]

\begin{tabular}{ll}
\hline \hline Cointegrating Eq: & CointEq1 \\
\hline \hline DIM(-1) & 1.000000 \\
DPIT(-1) & 1.202293 \\
& $(0.19222)$
\end{tabular}




\begin{tabular}{|c|c|c|}
\hline & [ 6.25464] & \\
\hline \multirow[t]{3}{*}{$\operatorname{DCIT}(-1)$} & 0.105955 & \\
\hline & $(0.17572)$ & \\
\hline & [0.60299] & \\
\hline \multirow[t]{3}{*}{ DVAT(-1) } & -2.437480 & \\
\hline & $(0.57227)$ & \\
\hline & {$[-4.25932]$} & \\
\hline \multirow[t]{3}{*}{ DPPT(-1) } & 0.497376 & \\
\hline & $(0.12387)$ & \\
\hline & [ 4.01522] & \\
\hline \multirow[t]{3}{*}{ DEXDT(-1) } & 0.715719 & \\
\hline & $(0.10221)$ & \\
\hline & [ 7.00239] & \\
\hline \multirow[t]{3}{*}{ DIMDT(-1) } & -1.609207 & \\
\hline & $(0.11590)$ & \\
\hline & {$[-13.8844]$} & \\
\hline $\mathrm{C}$ & 0.095029 & \\
\hline Error Correction: & $\mathrm{D}(\mathrm{DIM})$ & $\mathrm{D}(\mathrm{DPIT}) \quad \mathrm{D}(\mathrm{DCIT}) \quad \mathrm{D}(\mathrm{DVAT}) \quad \mathrm{D}(\mathrm{DPPT}) \quad \mathrm{D}(\mathrm{DEXDT}) \mathrm{D}(\mathrm{DIMDT})$ \\
\hline \multirow[t]{3}{*}{ CointEq1 } & -0.028316 & 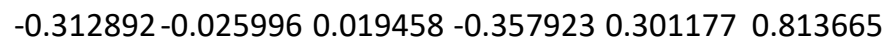 \\
\hline & $(0.03932)$ & $(0.15409)(0.10699)(0.03214)(0.18826)(0.27042)(0.15571)$ \\
\hline & {$[-0.72011]$} & {$[-2.03058][-0.24297][0.60549][-1.90124][1.11373][5.22538]$} \\
\hline \multirow[t]{3}{*}{$\mathrm{C}$} & $8.98 \mathrm{E}-19$ & $0.0028570 .008571-0.000952-0.020952-0.020476-0.017619$ \\
\hline & $(0.01160)$ & $(0.04548)(0.03158)(0.00948)(0.05556)(0.07981)(0.04596)$ \\
\hline & {$[7.7 e-17]$} & {$[0.06283][0.27145][-0.10042][-0.37712][-0.25657][-0.38340]$} \\
\hline R-squared & 0.026567 & 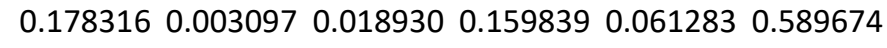 \\
\hline Adj. R-squared & -0.024666 & $0.135069-0.049371-0.0327050 .1156210 .0118770 .568078$ \\
\hline Sum sq. resids & 0.053733 & $\begin{array}{llllll}0.825159 & 0.397821 & 0.035888 & 1.231659 & 2.541384 & 0.842638\end{array}$ \\
\hline S.E. equation & 0.053180 & $\begin{array}{llllll}0.208397 & 0.144700 & 0.043461 & 0.254606 & 0.365728 & 0.210593\end{array}$ \\
\hline F-statistic & 0.518556 & 4.1232380 .0590340 .3666123 .6147261 .24039027 .30463 \\
\hline Log likelihood & 32.86883 & $4.18766111 .8481837 .10684-0.018028-7.6236673 .967564$ \\
\hline Akaike AIC & -2.939888 & $-0.208349-0.937922-3.3435080 .1921930 .916540-0.187387$ \\
\hline Schwarz SC & -2.840410 & $-0.108870-0.838444-3.2440300 .2916711 .016018-0.087909$ \\
\hline Mean dependent & 0.000000 & $0.0028570 .008571-0.000952-0.020952-0.020476-0.017619$ \\
\hline S.D. dependent & 0.052536 & $\begin{array}{llllll}0.224079 & 0.141255 & 0.042767 & 0.270738 & 0.367920 & 0.320436\end{array}$ \\
\hline \multicolumn{3}{|c|}{ Determinant resid covariance (dof adj.) 5.42E-14 } \\
\hline \multicolumn{2}{|c|}{ Determinant resid covariance } & $2.69 \mathrm{E}-14$ \\
\hline \multicolumn{2}{|c|}{ Log likelihood } & 119.5137 \\
\hline \multicolumn{2}{|c|}{ Akaike information criterion } & -9.382259 \\
\hline \multicolumn{2}{|c|}{ Schwarz criterion } & -8.337736 \\
\hline
\end{tabular}

Source: Researcher's computation using E-View 9.0, 2017

\section{Interpretation of Diagnostic Result}

This study employed the use of time series data for a period of 23 years ranging from 1994-2016. The multiple regression model was specified and then the residuals generated. The residuals were tested at first level and found to be stationary at 5\% critical level. The reafter, the Error Correction Model (ECM) was used. Meanwhile, the variables were individually tested for stationary at first difference; and they were found to be stationary on first difference. However the residuals found stationary, suggest that the variables were co-integrated in the long run.

Table 6 shows that the linear trend between DPIT, DCIT, DVAT, DPPT, DEXDT, DIMDT and DIM is cointegrated, that is, there is a long-term or equilibrium relationship between the dependent and independent variables. Of course, in the short-run there may disequilibrium and the equilibrium error 
(error term) could be tied to the short-run behaviour of DIM to its long-run value. This therefore gave rise to the formulation and subsequent use of the Error Correction Model (ECM).

An examination of the F-stat. which explains the overall significance of the model with a probability of 0.0000 , indicating that the model is statistically significant and that the model has the ability of explaining the actual behaviour of the dependent variable in the long run. Statistically, the ECM is significant, suggesting that DIM adjusts to PIT, CIT, VAT, PPT, EXDT, IMDT with a lag.

Test of Hypothesis II

$\mathrm{Ho}_{2}$ : Tax Revenue has no significant effect on Labour Force in Nigeria

$\mathbf{H}_{2}$ : Tax Revenue has significant effect on Labour Force in Nigeria

Model Specification

$L F=\beta_{0}+\beta_{1} P I T+\beta_{2} \mathrm{CIT}+\beta_{3} V A T+\beta_{4} P P T+\beta_{5} E X D T+\beta_{6} I M D T+\mu-H_{2}$

Table 7. Multiple Regression Analysis showing the relationship between DPIT, DCIT, DVAT, DPPT, DEXDT, DIMDT and DLF

Dependent Variable: DLF

Method: Least Squares

Date: 03/06/18 Time: 08:50

Sample (adjusted): 19952016

Included observations: 22 after adjustments

\begin{tabular}{lclcc}
\hline \hline \multicolumn{1}{c}{ Variable } & Coefficient & Std. Error & t-Statistic & Prob. \\
\hline \hline C & -0.000869 & 0.001157 & -0.751283 & 0.4641 \\
DPIT & -0.004995 & 0.008393 & -4.595073 & 0.0007 \\
DCIT & 0.015996 & 0.007771 & 2.058358 & 0.0474 \\
DVAT & -0.011914 & 0.024194 & -6.492437 & 0.0000 \\
DPPT & 0.002704 & 0.005149 & 5.525168 & 0.0001 \\
DEXDT & 0.003444 & 0.004565 & 0.754430 & 0.4623 \\
DIMDT & 0.004714 & 0.005181 & 0.909841 & 0.3773 \\
\hline \hline R-squared & 0.609670 & Mean dependent var & -0.000455 \\
Adjusted R-squared & 0.533538 & S.D. dependent var & 0.003751 \\
S.E. of regression & 0.003687 & Akaike info criterion & -8.114382 \\
Sum squared resid & 0.000204 & Schwarz criterion & -7.767233 \\
Log likelihood & 96.25821 & Hannan-Quinn criter. & -8.032604 \\
F-statistic & 71.21455 & Durbin-Watson stat & 1.951095 \\
Prob(F-statistic) & 0.005997 & & \\
\hline \hline
\end{tabular}

Source: Researcher's computation using E-View 9.0, 2018

\section{Interpretation of Regression Coefficient Result}

It is indicated in table 7 that there is a negative but statistically significant relationship between DPIT $\left(\beta_{1}=-0.004995\right)$, DVAT $\left(\beta_{3}=-0.011914\right)$ and DLF at $5 \%$ level of significance, a positive and significant relationship between $\mathrm{DCIT}\left(\beta_{2}=0.015996\right)$, DPPT $\left(\beta_{4}=0.002704\right)$ and DLF at $5 \%$ significant level, while a positive but non-significant relationship exist between DEXDT $\left(\beta_{5}=0.003444\right)$, DIMDT $\left(\beta_{6}=0.004714\right)$ and DLF. The slope coefficient of the regressed coefficient result indicates that $P\left(x_{1}=0.0007<0.05\right.$; $\left.\mathrm{x}_{2}=0.0474<0.05 ; \mathrm{x}_{3}=0.0000<0.05 ; \mathrm{x}_{4}=0.0001<0.05 ; \mathrm{x}_{5}=0.4623>0.05 ; \mathrm{x}_{6}=0.3773>0.05\right)$.

Testing the overall significance of the model, the results also confirmed that the model is statistically significant at $5 \%$ level of significance with the Prob(F-statistic) $=0.005997$. Durbin-Watson statistics of 1.716859 showed that the data are free from problem of serial correlation.

Decision Rule

Accept the alternative hypothesis $\left(\mathrm{H}_{1}\right)$ if the $\mathrm{p}$-value of the test is less than 0.05 , otherwise reject.

Decision:

The P-value of the test is 0.005997 which is less than the critical P-value of 0.05 . Hence, $\mathrm{H}_{\mathrm{o}}$ is rejected and $\mathrm{H}_{1}$ is accepted. 
Conclusion

Since there is strong evidence that labour force is influenced by tax revenues at $5 \%$ level of significance. This study concludes that taxation has significant influence on labour force in Nigeria for the period of 1994 to 2016.

Table 8. Granger Causality Test showing the Causality between DPIT, DCIT, DVAT, DPPT, DEXDT, DIMDT and DLF

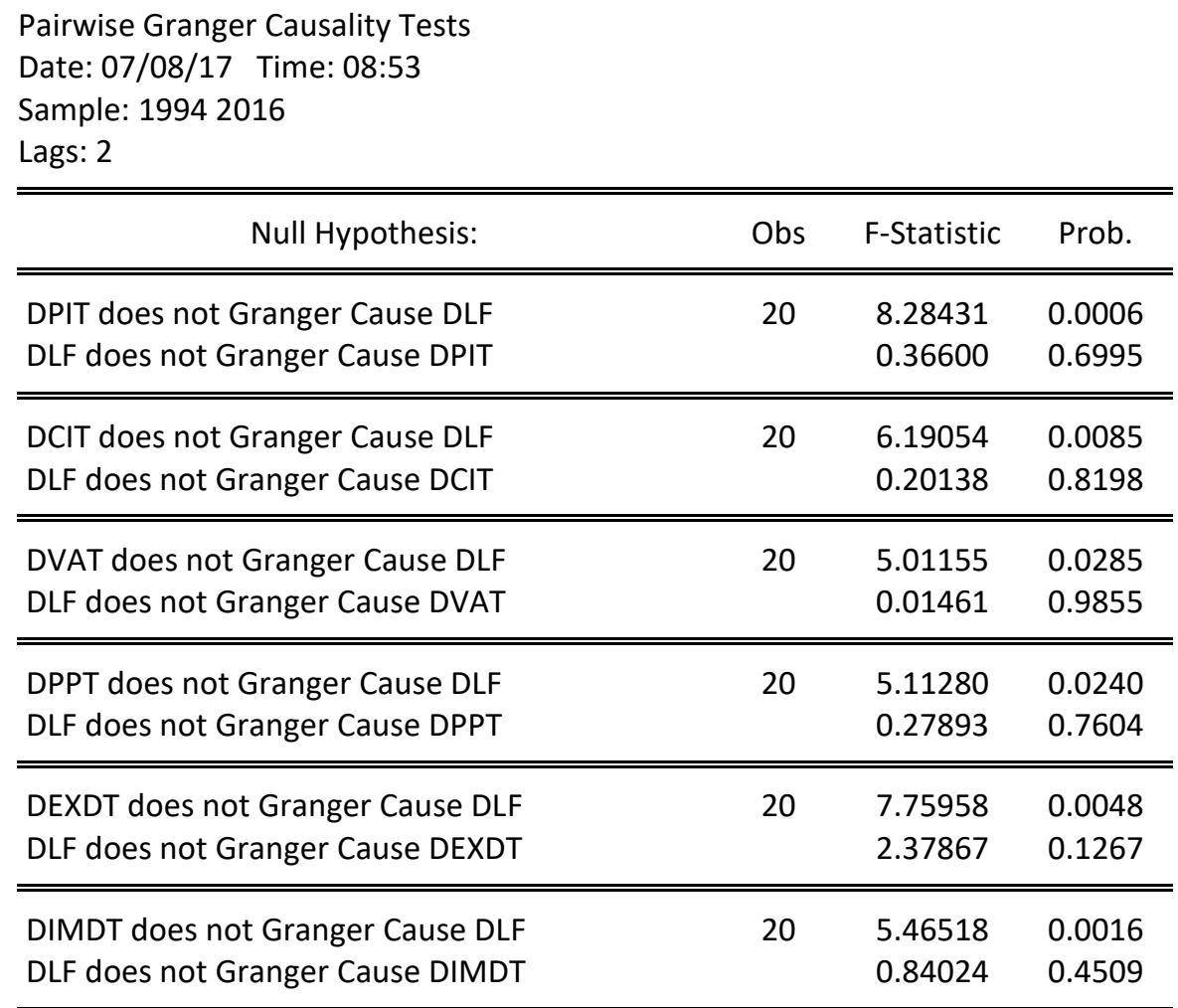

Source: Researcher's computation using E-View 9.0, 2017

\section{Interpretation of Post Regression Analysis}

Table 8 shows that there is a unilateral causality between DPIT, DCIT, DVAT, DPPT, DEXDT, DIMDT and DLF, since the P-values are statistically significant at $5 \%$ level. Moreover, at two (2) lags there is a statistically significant relationship between DPIT, DCIT, DVAT, DPPT, DEXDT, DIMDT and DLF. On the other hand, there is no reverse causation from DLF to DPIT, DCIT, DVAT, DPPT, DEXDT, DIMDT. This establishes the fact that DPIT, DCIT, DVAT, DPPT, DEXDT, DIMDT Granger Causes DLF. Consequently, the null hypothesis is rejected for the alternative which states that DPIT, DCIT, DVAT, DPPT, DEXDT, DIMDT has a statistically significant effect on DLF in Nigeria at $5 \%$ level of significance.

Table 9. Johansen Co-integration Test

Date: 03/06/18 Time: 08:55

Sample (adjusted): 19962016

Included observations: 21 after adjustments

Trend assumption: Linear deterministic trend

Series: DLF DPIT DCIT DVAT DPPT DEXDT DIMDT

Lags interval (in first differences): No lags

Unrestricted Cointegration Rank Test (Trace)

\begin{tabular}{lcccc}
\hline \hline $\begin{array}{l}\text { Hypothesized } \\
\text { No. of CE(s) }\end{array}$ & Eigenvalue & $\begin{array}{c}\text { Trace } \\
\text { Statistic }\end{array}$ & $\begin{array}{c}0.05 \\
\text { Critical Value }\end{array}$ & Prob.** \\
\hline \hline None ${ }^{*}$ & 0.928489 & 161.5976 & 125.6154 & 0.0001
\end{tabular}




\begin{tabular}{lllll}
\hline At most $1 *$ & 0.798831 & 106.2017 & 95.75366 & 0.0009 \\
At most 2 & 0.714967 & 72.52589 & 69.81889 & 0.0014 \\
At most 3 & 0.618604 & 59.16774 & 47.85613 & 0.0017 \\
At most 4 & 0.581235 & 55.92548 & 45.79707 & 0.0109 \\
At most 5 & 0.565949 & 53.31747 & 43.49471 & 0.0127 \\
At most 6 & 0.535182 & 51.41547 & 40.84146 & 0.0241 \\
\hline \hline
\end{tabular}

Trace test indicates 7 cointegrating eqn(s) at the 0.05 level

$*$ denotes rejection of the hypothesis at the 0.05 level

**MacKinnon-Haug-Michelis (1999) p-values

Unrestricted Cointegration Rank Test (Maximum Eigenvalue)

\begin{tabular}{|c|c|c|c|c|}
\hline $\begin{array}{l}\text { Hypothesized } \\
\text { No. of CE(s) }\end{array}$ & Eigenvalue & $\begin{array}{l}\text { Max-Eigen } \\
\text { Statistic }\end{array}$ & $\begin{array}{c}0.05 \\
\text { Critical Value }\end{array}$ & Prob.** \\
\hline None * & 0.928489 & 75.39593 & 66.23142 & 0.0000 \\
\hline At most $1 *$ & 0.798831 & 71.67577 & 63.07757 & 0.0000 \\
\hline At most $2 *$ & 0.714967 & 66.35814 & 58.87687 & 0.0002 \\
\hline At most $3^{*}$ & 0.618604 & 65.24227 & 57.58434 & 0.0046 \\
\hline At most $4^{*}$ & 0.581235 & 62.60801 & 55.13162 & 0.0073 \\
\hline At most $5^{*}$ & 0.565949 & 53.90199 & 50.26460 & 0.0184 \\
\hline At most $6^{*}$ & 0.535182 & 51.41547 & 49.84146 & 0.0341 \\
\hline
\end{tabular}

Max-eigenvalue test indicates 7 cointegrating eqn(s) at the 0.05 level

* denotes rejection of the hypothesis at the 0.05 level

**MacKinnon-Haug-Michelis (1999) p-values

Source: Researcher's computation using E-View 9.0, 2018

\section{Interpretation of Diagnostic Result}

In table 9, the Johansen co-integration test was used to determine the existence of long-run equilibrium relationship among the variables under study. The Trace Statistic value and Max-Eigen Statistic are shown to be greater than the critical values at $1 \%$ and $5 \%$ levels, thus indicating 7 co-integrating equation at $5 \%$ levels. Therefore, the null hypothesis is rejected and it is concluded that there exists long run equilibrium relationship between the dependent variable (DLF) and independent variables (DPIT, DCIT, DVAT, DPPT, DEXDT, DIMDT). This implies that the regression model is not spurious and the conclusion thereof is valid.

Table 10. Error Correction Model

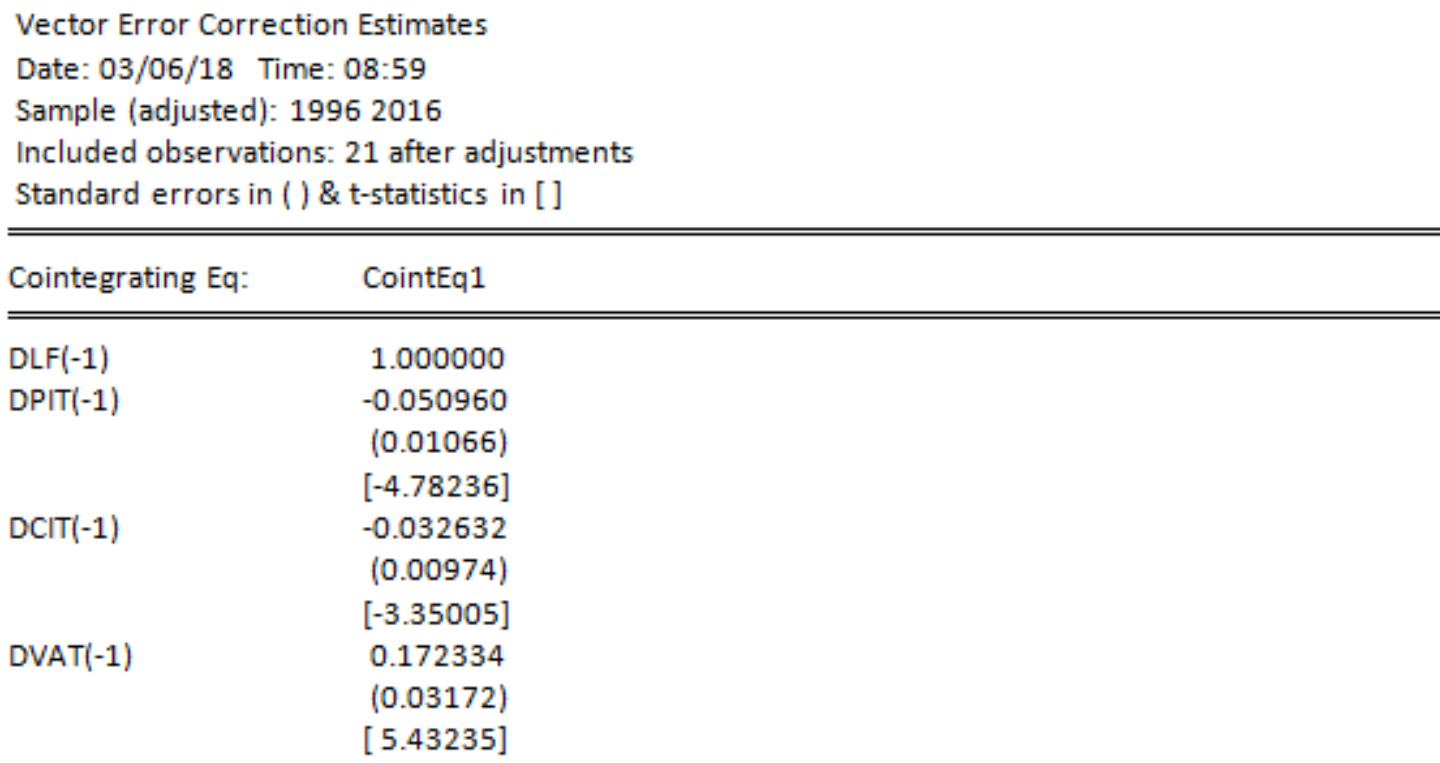




\begin{tabular}{|c|c|c|}
\hline \multirow[t]{3}{*}{ DPPT(-1) } & -0.040027 & \\
\hline & $(0.00687)$ & \\
\hline & {$[-5.82897]$} & \\
\hline \multirow[t]{3}{*}{ DEXDT(-1) } & -0.040322 & \\
\hline & $(0.00567)$ & \\
\hline & {$[-7.11654]$} & \\
\hline \multirow[t]{3}{*}{ DIMDT(-1) } & 0.075372 & \\
\hline & $(0.00642)$ & \\
\hline & [ 11.7312] & \\
\hline $\mathrm{C}$ & -0.005067 & \\
\hline Error Correction: & $\mathrm{D}(\mathrm{DLF})$ & $\mathrm{D}(\mathrm{DPIT}) \quad \mathrm{D}(\mathrm{DCIT}) \quad \mathrm{D}(\mathrm{DVAT}) \quad \mathrm{D}(\mathrm{DPPT}) \quad \mathrm{D}(\mathrm{DEXDT}) \mathrm{D}(\mathrm{DIMDT})$ \\
\hline \multirow[t]{3}{*}{ CointEq1 } & -0.164249 & $5.6101691 .064204-0.5834597 .647595-4.379832-14.10109$ \\
\hline & $(0.06875)$ & $(2.93801)(2.00718)(0.59738)(3.45556)(5.16980)(3.25174)$ \\
\hline & {$[-2.38892]$} & {$[1.90952][0.53020][-0.97670][2.21313][-0.84720][-4.33648]$} \\
\hline \multirow[t]{3}{*}{$\mathrm{C}$} & $-4.34 \mathrm{E}-19$ & $0.0028570 .008571-0.000952-0.020952-0.020476-0.017619$ \\
\hline & $(0.00108)$ & $(0.04595)(0.03139)(0.00934)(0.05405)(0.08086)(0.05086)$ \\
\hline & {$[-4.0 e-16]$} & {$[0.06218][0.27303][-0.10193][-0.38767][-0.25323][-0.34643]$} \\
\hline R-squared & 0.230985 & $\begin{array}{llllll}0.161009 & 0.014580 & 0.047807 & 0.204952 & 0.036401 & 0.497421\end{array}$ \\
\hline Adj. R-squared & 0.190510 & $0.116852-0.037285-0.0023080 .163107-0.0143150 .470970$ \\
\hline Sum sq. resids & 0.000461 & 0.8425390 .3932390 .0348321 .1655252 .6087481 .032086 \\
\hline S.E. equation & 0.004928 & $\begin{array}{llllll}0.210580 & 0.143864 & 0.042817 & 0.247676 & 0.370544 & 0.233067\end{array}$ \\
\hline F-statistic & 5.706928 & 3.6462510 .2811110 .9539484 .8979310 .71774018 .80503 \\
\hline Log likelihood & 82.82265 & $3.96880111 .9698237 .420540 .561473-7.8983621 .838166$ \\
\hline Akaike AIC & -7.697395 & $-0.187505-0.949507-3.3733850 .1370030 .9427010 .015413$ \\
\hline Schwarz SC & -7.597916 & $-0.088027-0.850028-3.2739060 .2364811 .0421790 .114891$ \\
\hline Mean dependent & 0.000000 & $0.0028570 .008571-0.000952-0.020952-0.020476-0.017619$ \\
\hline S.D. dependent & 0.005477 & $\begin{array}{llllll}0.224079 & 0.141255 & 0.042767 & 0.270738 & 0.367920 & 0.320436\end{array}$ \\
\hline \multicolumn{2}{|c|}{ Determinant resid covariance (dof adj.) } & $4.83 E-16$ \\
\hline \multicolumn{2}{|c|}{ Determinant resid covariance } & $2.40 \mathrm{E}-16$ \\
\hline \multicolumn{2}{|c|}{ Log likelihood } & 169.0615 \\
\hline \multicolumn{2}{|c|}{ Akaike information criterion } & -14.10110 \\
\hline \multicolumn{2}{|c|}{ Schwarz criterion } & -13.05657 \\
\hline
\end{tabular}

Source: Researcher's computation using E-View 9.0, 2018

\section{Interpretation of Diagnostic Result}

This study employed the use of time series data for a period of 23 years ranging from 1994-2016. The multiple regression model was specified and then the residuals generated. The residuals were tested at first level and found to be stationary at $5 \%$ critical level. Thereafter, the Error Correction Model (ECM) was used. Meanwhile, the variables were individually tested for stationary at first difference; and they were found to be stationary on first difference. However the residuals found stationary, suggest that the variables were co-integrated in the long run.

Table 10 shows that the linear trend between DPIT, DCIT, DVAT, DPPT, DEXDT, DIMDT and DLF is cointegrated, that is, there is a long-term or equilibrium relationship between the dependent and independent variables. Of course, in the short-run there may disequilibrium and the equilibrium error (error term) could be tied to the short-run behaviour of DLF to its long-run value. This therefore gave rise to the formulation and subsequent use of the Error Correction Model (ECM).

An examination of the F-stat. which explains the overall significance of the model with a probability of 0.0000 , indicating that the model is statistically significant and that the model has the ability of explaining the actual behaviour of the dependent variable in the long run. Statistically, the ECM is significant, suggesting that DLF adjusts to PIT, CIT, VAT, PPT, EXDT, IMDT with a lag. 
Test of Hypothesis III

$\mathrm{Ho}_{3}$ : Tax Revenue has no significant effect on GFCF in Nigeria.

$\mathbf{H}_{3}$ : Tax Revenue has significant effect on GFCF in Nigeria.

Model Specification

$\mathrm{GFCF}=\beta_{0}+\beta_{1} \mathrm{PIT}+\beta_{2} \mathrm{CIT}+\beta_{3} \mathrm{VAT}+\beta_{4} \mathrm{PPT}+\beta_{5} \mathrm{EXDT}+\beta_{6} \mathrm{IMDT}+\mu \mathrm{Ho}_{3}$

Table 11. Multiple Regression Analysis showing the relationship between DPIT, DCIT, DVAT, DPPT, DEXDT, DIMDT and DGFCF

\begin{tabular}{|c|c|c|c|c|}
\hline Variable & Coefficient & Std. Error & t-Statistic & Prob. \\
\hline C & 0.082039 & 0.039994 & 2.051289 & 0.0581 \\
\hline DPIT & 0.051401 & 0.290050 & 0.177214 & 0.8617 \\
\hline DCIT & -0.122681 & 0.268562 & -7.456806 & 0.0000 \\
\hline DVAT & 0.739525 & 0.836067 & 5.884529 & 0.0004 \\
\hline DPPT & -0.018286 & 0.177922 & -0.102778 & 0.9195 \\
\hline DEXDT & 0.091769 & 0.157753 & 4.581730 & 0.0094 \\
\hline DIMDT & -0.216228 & 0.179042 & -6.207697 & 0.0000 \\
\hline R-squared & 0.858206 & \multicolumn{2}{|c|}{ Mean dependent var } & 0.105000 \\
\hline Adjusted R-squared & 0.778511 & \multicolumn{2}{|c|}{ S.D. dependent var } & 0.117382 \\
\hline S.E. of regression & 0.127429 & \multicolumn{2}{|c|}{ Akaike info criterion } & -1.029141 \\
\hline Sum squared resid & 0.243573 & \multicolumn{2}{|c|}{ Schwarz criterion } & -0.681991 \\
\hline Log likelihood & 18.32055 & \multirow{2}{*}{\multicolumn{2}{|c|}{$\begin{array}{l}\text { Hannan-Quinn criter. } \\
\text { Durbin-Watson stat }\end{array}$}} & -0.947362 \\
\hline F-statistic & 23.46984 & & & 1.020625 \\
\hline Prob(F-statistic) & 0.000149 & & & \\
\hline
\end{tabular}

Source: Researcher's computation using E-View 9.0, 2018

\section{Interpretation of Regression Result}

The function of the multiple regressions in table 11 was built in the model below:

DGFCF=0.082039+0.051401DPIT-0.122681DCIT+0.739525DVAT-0.018286DPPT+0.091769DEXDT-

\section{$0.216228 \mathrm{DIMDT}$.}

The results of the multiple regressions exploring the functional relationship between DPIT, DCIT, DVAT, DPPT, DEXDT, DIMDT and DGFCF are presented in table 11 The results showed that DPIT, DVAT and DEXDT have a direct/positive relationship with DGFCF while DCIT, DPPT and DIMDT have negative relationship with DGFCF in Nigeria. This implies that Gross Fixed Capital Formation is significantly influenced by the explanatory variables. The result also showed that DCIT, DVAT, DEXDT and DIMDT are statistically significant in explaining variations in Gross Fixed Capital Formation at $5 \%$ level of significance. Testing the overall significance of the model, the results also confirmed that the model is statistically significant at $5 \%$ level of significance with the Prob(F-statistic) $=0.000149$. Durbin-Watson statistics of 1.020625 showed that the data are free from problem of serial correlation.

Decision Rule

Reject $H_{0}$ if the P-value of the test is less than $\alpha$-value (level of significance) at $5 \%$, otherwise accept $\mathrm{H}_{1}$

\section{Decision}

The P-value of the test (Prob > F $=0.000149$ ) is less than 0.05. In view of the rule of thumb, $\mathrm{H}_{1}$ will be accepted and $\mathrm{H}_{0}$ rejected. 
Conclusion

It would be concluded that tax revenues have a statistically significant effect on Gross Fixed Capital Formation in Nigeria at $5 \%$ level of significance.

Table 12. Granger Causality Test showing the Causality between DPIT, DCIT, DVAT, DPPT, DEXDT, DIMDT and DGFCF

\begin{tabular}{|c|c|c|c|}
\hline Null Hypothesis: & Obs & F-Statistic & Prob. \\
\hline DPIT does not Granger Cause DGFCF & 20 & 4.08835 & 0.0383 \\
\hline DGFCF does not Granger Cause DPIT & & 0.66155 & 0.5305 \\
\hline DCIT does not Granger Cause DGFCF & 20 & 7.37380 & 0.0043 \\
\hline DGFCF does not Granger Cause DCIT & & 1.51187 & 0.2523 \\
\hline DVAT does not Granger Cause DGFCF & 20 & 7.39325 & 0.0046 \\
\hline DGFCF does not Granger Cause DVAT & & 1.12260 & 0.3513 \\
\hline DPPT does not Granger Cause DGFCF & 20 & 9.82203 & 0.0001 \\
\hline DGFCF does not Granger Cause DPPT & & 2.96403 & 0.0823 \\
\hline DEXDT does not Granger Cause DGFCF & 20 & 5.14832 & 0.0334 \\
\hline DGFCF does not Granger Cause DEXDT & & 1.30711 & 0.2997 \\
\hline DIMDT does not Granger Cause DGFCF & 20 & 6.01650 & 0.0135 \\
\hline DGFCF does not Granger Cause DIMDT & & 2.14452 & 0.1517 \\
\hline
\end{tabular}

Source: Researcher's computation using E-View 9.0, 2018

\section{Interpretation of Post Regression Analysis}

Table 12 shows that there is a unilateral causality between DPIT, DCIT, DVAT, DPPT, DEXDT, DIMDT and DGFCF, since the P-values are statistically significant at $5 \%$ level. Moreover, at two (2) lags there is a statistically significant relationship between DPIT, DCIT, DVAT, DPPT, DEXDT, DIMDT and DGFCF. On the other hand, there is no reverse causation from DGFCF to DPIT, DCIT, DVAT, DPPT, DEXDT, DIMDT. This establishes the fact that DPIT, DCIT, DVAT, DPPT, DEXDT, DIMDT Granger Causes DGFCF. Consequently, the null hypothesis is rejected for the alternative which states that DPIT, DCIT, DVAT, DPPT, DEXDT, DIMDT has a statistically significant effect on DGFCF in Nigeria at $5 \%$ level of significance.

Table 13. Johansen Co-integration Test

Date: 03/06/18 Time: 09:22

Sample (adjusted): 19962016

Included observations: 21 after adjustments

Trend assumption: Linear deterministic trend

Series: DGFCF DPIT DCIT DVAT DPPT DEXDT DIMDT

Lags interval (in first differences): No lags

Unrestricted Cointegration Rank Test (Trace)

\begin{tabular}{lcccc}
\hline \hline $\begin{array}{l}\text { Hypothesized } \\
\text { No. of CE(s) }\end{array}$ & Eigenvalue & $\begin{array}{c}\text { Trace } \\
\text { Statistic }\end{array}$ & $\begin{array}{c}0.05 \\
\text { Critical Value }\end{array}$ & Prob. $^{* *}$ \\
\hline \hline None ${ }^{*}$ & 0.957604 & 190.2461 & 125.6154 & 0.0000 \\
At most 1 & 0.795090 & 123.8716 & 95.75366 & 0.0002
\end{tabular}




\begin{tabular}{|c|c|c|c|c|}
\hline At most $2 *$ & 0.785641 & 90.58264 & 69.81889 & 0.0005 \\
\hline At most $3 *$ & 0.701028 & 58.24051 & 47.85613 & 0.0039 \\
\hline At most $4 *$ & 0.582803 & 32.88502 & 29.79707 & 0.0214 \\
\hline At most $5 *$ & 0.448555 & 24.52689 & 15.49471 & 0.0396 \\
\hline At most $6^{*}$ & 0.292030 & 13.02743 & 10.84146 & 0.0445 \\
\hline \multicolumn{5}{|c|}{$\begin{array}{l}\text { Trace test indicates } 7 \text { cointegrating eqn(s) at th } \\
* \text { denotes rejection of the hypothesis at the } 0.0 \\
* * \text { MacKinnon-Haug-Michelis (1999) p-values }\end{array}$} \\
\hline \multicolumn{5}{|c|}{ Unrestricted Cointegration Rank Test (Maximum Eigenvalue) } \\
\hline $\begin{array}{l}\text { Hypothesized } \\
\text { No. of CE(s) }\end{array}$ & Eigenvalue & $\begin{array}{l}\text { Max-Eigen } \\
\text { Statistic }\end{array}$ & $\begin{array}{l}0.05 \\
\text { Critical Value }\end{array}$ & Prob.** \\
\hline None * & 0.957604 & 66.37451 & 56.23142 & 0.0000 \\
\hline At most $1 *$ & 0.795090 & 53.28892 & 48.07757 & 0.0006 \\
\hline At most $2 *$ & 0.785641 & 46.34213 & 43.87687 & 0.0034 \\
\hline At most $3^{*}$ & 0.701028 & 35.35549 & 31.58434 & 0.0039 \\
\hline At most $4^{*}$ & 0.582803 & 28.35813 & 21.13162 & 0.0170 \\
\hline At most $5^{*}$ & 0.448555 & 19.49946 & 14.26460 & 0.0333 \\
\hline At most $6 *$ & 0.292030 & 13.02743 & 10.84146 & 0.0445 \\
\hline
\end{tabular}

Max-eigenvalue test indicates 7 cointegrating eqn(s) at the 0.05 level

* denotes rejection of the hypothesis at the 0.05 level

Source: Researcher's computation using E-View 9.0, 2018

\section{Interpretation of Diagnostic Result}

In table 13, the Johansen co-integration test was used to determine the existence of long-run equilibrium relationship among the variables under study. The Trace Statistic value and Max-Eigen Statistic are shown to be greater than the critical values at $1 \%$ and $5 \%$ levels, thus indicating 7 co-integrating equation at $5 \%$ levels. Therefore, the null hypothesis is rejected and it is concluded that there exists long run equilibrium relationship between the dependent variable (DGFCF) and independent variables (DPIT, DCIT, DVAT, DPPT, DEXDT, DIMDT). This implies that the regression model is not spurious and the conclusion thereof is valid.

\section{Table 14. Error Correction Model}

Vector Error Correction Estimates

Date: 03/06/18 Time: 09:25

Sample (adjusted): 19962016

Included observations: 21 after adjustments

Standard errors in ( ) \& t-statistics in [ ]

\begin{tabular}{lc}
\hline \hline Cointegrating Eq: & CointEq1 \\
\hline \hline DGFCF(-1) & 1.000000 \\
DPIT(-1) & 2.289514 \\
& $(0.30438)$ \\
& {$[7.52187]$} \\
DCIT(-1) & -0.406704 \\
& $(0.27824)$ \\
& {$[-1.46170]$} \\
DVAT(-1) & -4.837098 \\
& $(0.90617)$ \\
DPPT(-1) & {$[-5.33796]$} \\
& 1.835810 \\
\end{tabular}




\begin{tabular}{|c|c|c|}
\hline \multirow{3}{*}{ DEXDT(-1) } & [ 9.35927] & \\
\hline & 0.975151 & \\
\hline & $(0.16185)$ & \\
\hline & [ 6.02513] & \\
\hline \multirow[t]{3}{*}{ DIMDT(-1) } & -2.433836 & \\
\hline & $(0.18352)$ & \\
\hline & {$[-13.2616]$} & \\
\hline $\mathrm{C}$ & 0.037777 & \\
\hline Error Correction: & $D(D G F C F)$ & $\mathrm{D}(\mathrm{DCIT}) \quad \mathrm{D}(\mathrm{DVAT}) \quad \mathrm{D}(\mathrm{DPPT}) \quad \mathrm{D}(\mathrm{DEXDT}) \mathrm{D}(\mathrm{DIMDT})$ \\
\hline \multirow[t]{3}{*}{ CointEq1 } & -0.177974 & 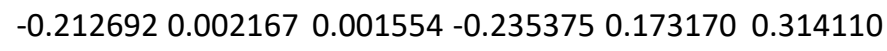 \\
\hline & $(0.05283)$ & $(0.06977)(0.05367)(0.01625)(0.08755)(0.13402)(0.09813)$ \\
\hline & {$[-3.36850]$} & {$[-3.04861][0.04037][0.09567][-2.68841][1.29208][3.20096]$} \\
\hline \multirow[t]{3}{*}{$\mathrm{C}$} & -0.005238 & $0.0028570 .008571-0.000952-0.020952-0.020476-0.017619$ \\
\hline & $(0.03113)$ & $(0.04111)(0.03162)(0.00957)(0.05159)(0.07898)(0.05782)$ \\
\hline & {$[-0.16824]$} & {$[0.06950][0.27104][-0.09949][-0.40612][-0.25927][-0.30470]$} \\
\hline R-squared & 0.373904 & $\begin{array}{llllll}0.328480 & 0.000086 & 0.000481 & 0.275570 & 0.080770 & 0.350341\end{array}$ \\
\hline Adj. R-squared & 0.340951 & $0.293137-0.052541-0.0521250 .2374420 .0323890 .316149$ \\
\hline Sum sq. resids & 0.386755 & 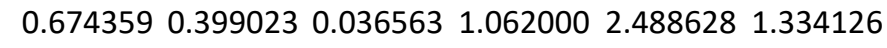 \\
\hline S.E. equation & 0.142673 & $\begin{array}{llllll}0.188395 & 0.144918 & 0.043868 & 0.236421 & 0.361912 & 0.264985\end{array}$ \\
\hline F-statistic & 11.34677 & 9.2940320 .0016300 .0091537 .2275241 .66946710 .24613 \\
\hline Log likelihood & 12.14441 & $6.30669511 .8165136 .911221 .538157-7.403404-0.857128$ \\
\hline Akaike AIC & -0.966134 & 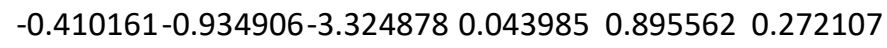 \\
\hline Schwarz SC & -0.866656 & $-0.310683-0.835427-3.2254000 .1434630 .9950410 .371586$ \\
\hline Mean dependent & -0.005238 & $0.0028570 .008571-0.000952-0.020952-0.020476-0.017619$ \\
\hline S.D. dependent & 0.175745 & $\begin{array}{llllll}0.224079 & 0.141255 & 0.042767 & 0.270738 & 0.367920 & 0.320436\end{array}$ \\
\hline \multicolumn{3}{|c|}{ Determinant resid covariance (dof adj.) 4.20E-13 } \\
\hline \multicolumn{2}{|c|}{ Determinant resid covariance } & $2.09 \mathrm{E}-13$ \\
\hline \multicolumn{2}{|c|}{ Log likelihood } & 98.00156 \\
\hline \multicolumn{2}{|c|}{ Akaike information criterion } & -7.333482 \\
\hline \multicolumn{2}{|c|}{ Schwarz criterion } & -6.288959 \\
\hline
\end{tabular}

Source: Researcher's computation using E-View 9.0, 2018

\section{Interpretation of Diagnostic Result}

This study employed the use of time series data for a period of 23 years ranging from 1994-2016. The multiple regression model was specified and then the residuals generated. The residuals were tested at first level and found to be stationary at 5\% critical level. Thereafter, the Error Correction Model (ECM) was used. Meanwhile, the variables were individually tested for stationary at first difference; and they were found to be stationary on first difference. However the residuals found stationary, suggest that the variables were co-integrated in the long run.

Table 14 shows that the linear trend between DPIT, DCIT, DVAT, DPPT, DEXDT, DIMDT and DLF is cointegrated, that is, there is a long-term or equilibrium relationship between the dependent and independent variables. Of course, in the short-run there may disequilibrium and the equilibrium error (error term) could be tied to the short-run behaviour of DGFCF to its long-run value. This therefore gave rise to the formulation and subsequent use of the Error Correction Model (ECM).

An examination of the F-stat. which explains the overall significance of the model with a probability of 0.0000 , indicating that the model is statistically significant and that the model has the ability of explaining the actual behavior of the dependent variable in the long run. Statistically, the ECM is significant, suggesting that DGFCF adjusts to PIT, CIT, VAT, PPT, EXDT, and IMDT with a lag. 


\section{Findings, Conclusions and Recommendations}

\section{Findings}

Based on the analysis of data, the following findings emerged:

1. That Tax Revenue significantly affects Infant Mortality (IM) in Nigeria at $5 \%$ level of significance.

2. That Tax Revenue significantly affects Labour Force (LF) in Nigeria at $5 \%$ level of significance.

3. That Tax Revenue significantly affects Gross Fixed Capital formation (GFCF) in Nigeria at $5 \%$ level of significance.

\section{Recommendations}

The following recommendations are made in line with the findings of this study:

1. Government should ensure that the tax revenues are expended judiciously in Nigeria, in order to ensure that marginal benefits are accrued for all members of the economy in a bid to reducing infant mortality in Nigeria.

2. Since there is a significant relationship between tax revenue and labour force Government needs to increase its allocation to the priority sectors of the economy such as agriculture and industry in order improve on the welfare of the citizenry.

3. Based on the finding that tax revenue significantly relates with gross fixed capital formation in Nigeria, there is need for government to provide an enabling environment for investment purposes. Existing infrastructural facilities should be improved. Thus, government spending in these areas has to be enhanced.

\section{References}

1. Abu N. \& Abdullahi, U. (2011). Government expenditure and economic growth in Nigeria, 19702008: A disaggregated analysis. Business and Economics Journal, 4(1), 1-11.

2. Abiahu, M.F., \& Amahalu, N.N. (2017). Effect of taxation on dividend policy of quoted deposit money banks in Nigeria (2006-2015). EPH - International Journal of Business \& Management Science, 130.

3. Amahalu, N.N., \& Ezechukwu, B.O. (2017). Determinants of audit quality: Evidence from deposit money banks listed on Nigeria Stock Exchange, International Journal of Academic Research in Accounting, Finance and Management Sciences, 7(2), 117-130.

4. Amahalu, N.N., Nweze, C.L., \& Obi, J.C. (2017). Effect of backflush accounting on financial performance of quoted food and beverage firms in Nigeria. EPH - International Journal of Medical and Health Science, 2(3), 58-80

5. Amahalu, N.N., Okeke, M.N., \& Obi, J.C. (2017). Audit quality determinants: Evidence from quoted health care firms in Nigeria. International Journal of Academic Research in Accounting, Finance and Management Sciences, 7(4), 216-231.

6. Appah, E. (2010). The problems of tax planning and administration in Nigeria: The Federal and State Governments Experience. Int. J. Lab. Organ.. Psychol., 4(1-2): 1-14.

7. Azubike, J.U.B., (2009). Challenges of tax authorities, tax payers in the management of tax reform processes. Nigerian Accountant, 42 (2), $36-42$

8. Azuka, E.B. (2011). Research methods: Theory and applications. Dataword Computer, Oko, Nigeria.

9. Bakare A.S (2011). A theoretical analysis of capital formation and growth in Nigeria, Far East Journal of Psychology and Business, 3(1) April 2011

10.Black, R.E., \& Li, L. (2012). Global under five mortality: where do we stand today? Johns Hopkins, Bloomberg School of public health for the child health Epidemiology Reference Group of WHO and UNICEF.

11.Central Bank of Nigeria, Statistical Bulletin (2015), CBN, Abuja

12.Collier, P., \& Gunning, J. (1999). Explaining African economic performance. Journal of economic literature ECA, 1995.Human Development in Africa: 1995 Report, Economic Commission for Africa, Addis Ababa. 
13.Devarajan S. (1996). The relationship between government expenditure and economic growth. Journal of Monetary Economics, 37, 313-344.

14.Dritsakis, N, (2003). Hungarian macroeconomic variables - reflection on causal relationships, Acta Oeconomica, 53(1), 61-73.

15.Duranton, G. (2011). California dreaming: The feeble case for cluster policies. Review of Economic Analysis, 3(1), 3-45.

16.Edame, E. (2008). The essential of public finance and public financial management in Nigeria. Revised 3rd Edition: Calabar, Wusen Press Ltd.

17.Edame, G.E., \& Okoi, W.W. (2014). The impact of taxation on investment and economic development in Nigeria. Academic Journal of Interdisciplinary Studies. 3(4). 209-218.

18.Fagbemi, T.O., Uadiale, O.M., \& Noah, A.O. (2010). The ethics of tax evasion: Perceptual evidence from Nigeria. European Journal of Social Sciences, 17(3), 360-371.

19.Feldman, M. P., \& Francis, J. (2003). Fortune favors the prepared region: The Case of entrepreneurship and the capitol region biotechnology cluster. European Planning Studies, 11 (7): 765-788.

20.Galbraith, J. K. (1960). The liberal hour. London: Hamish Hamilton Ltd.

21.Gambrah, P.P., \& Adzadu, Y. (2013). Using Markov chain to predict the probability of rural and urban child mortality rates reduction in Ghana. International Journal of Scientific \& Technology Research, 2(11), November 2013. 73-78.

22.Ihendinihu, J. U., Jones, E., \& Nwaiwu, J. N. (2014). Total revenue and economic growth in Nigeria: Empirical evidence. Journal of Emerging Trends in Economics and Management Sciences (JETEMS) 6(1), 4046.

23.Isola, W.A and Alani, R.A. (2002). Human capital development and economic growth: Empirical Evidence from Nigeria. Asian Economic and Financial Review. Journal homepage: //aessweb .com /journaldetail.php?d

24.Mba, I.C., Mba, E, I., Ogbuabor, J.E., \& Ikpegbu, C.H. (2013). Human capital development and economic growth in Nigeria, Journal of Economics and Sustainable Development, 4(18).

25.Murkur, G. A. (2001) Design of tax and corruption. Conference paper on "fighting corruption: Common Challenges and Shared Experiences".

26.Nzotta, S. M. (2007). Tax evasion problems in Nigeria. A critique Nigeria account. 12(1): 40- 43.

27.Oboh, C. S., \& Isa, E.F. (2012). An empirical investment of multiple tax practices and taxpayer's compliance in Nigeria (Unpublished Research Work).

28.Odo S.I., Eze, O.R., \& Onyeisi, S.O. (2016). Analysis of the relationship between human capital development and economic growth in Nigeria. European Journal of Accounting, Auditing and Finance Research, 4(3), 56-71.

29.OECD (2001). Export duty. https://stats.oecd.org/glossary/detail.asp?ID=910. Retrieved 24.6.2017

30.Okoli N.M., Ogbuewu, I.P., Okechukwu, K.C., Emenalom, I.C. (2014). Taxation and economic growth in Nigeria. International Journal of Research in Management, Science \& Technology, 2(3), 1-17.

31.Okpe, I. I. (2000). Personal income tax in Nigeria. Enugu: Ochumba Printing and Publishing Company

32.Omotoso, M. 0. (2001). Principles of taxation. (1st ed.) Ibadan: DFirst Shepherd Investment.

33.Oremade T. (2006). Petroleum profit tax in Nigeria. Ibadan: Evans Brothers Nigeria Publishers.

34.Soludo, C.C. (1998). Trade policy reforms and supply responses in Africa. UNCTAD Discussion papers.

35.World Health Organisation, WHO (2011). Child mortality: Millennium development goal (MDG) 4. The Partner for Maternal and New Born Birth, World Health Organisation. September, 2011. http://www.who.int/pmnch/media/press_materials/fs/fs_mdg4_childmortality/en/ 